\title{
Erzurum İli Hınıs İlçesinde Farklı Bitkilerin Yetiştirildiği Toprakların Bazı Fiziksel ve Kimyasal Özelliklerinin Araştırılması
}

\author{
Elif YAĞANOĞLU* \\ Adil AYDIN \\ Atatürk Üniversitesi Ziraat Fakültesi Toprak Bilimi ve Bitki Besleme Bölümü, Erzurum. \\ (Sorumlu yazar: elifyaganoglu@ atauni.edu.tr)
}

Geliş Tarihi :22.03.2017

Kabul Tarihi :23.05.2017

\begin{abstract}
ÖZET : Bu araştırma Erzurum ili Hınıs Ovası tarım topraklarının verimlilik durumunu belirlemek amacı ile yapılmıştır. Bu amaçla Erzurum ili Hınıs ilçe merkezinin dört bir yanından (Doğu, Batı, Güney ve Kuzey), farklı kültür altındaki (kuru tarım, sulu tarım ve çayır)arazilerden $0-30 \mathrm{~cm}$ derinlikten alınan 36 adet toprak örneği üzerinde yürütülmüştür. Toprak örneklerinde pH, E.C, kireç, organik madde, yarayışlı $\mathrm{P}, \mathrm{KDK}$, değişebilir $\mathrm{Na}$ ve K iletekstür analizleri yapılmıştır.Araştırma yöresi toprak örneklerinin analiz sonuçları ile sınır değerler karşılaştırılarak yöre topraklarının verimlilik durumları ile üretim potansiyelleri belirlenmeye çalışılmıştır. Analiz sonuçlarına göre araştırma yöresi toprak örneklerininnötr (\%58.3) ve hafif alkalin (\%41.7), tuzsuz (\%100), orta (\%75.0) ve fazla kireçli (\%25.0) olduğu, organik madde içeriği yönünden az (\%25.0), orta (\%58.3), fazla (\%16.7) sinıfinda yer aldığı, elverişli $\mathrm{P}_{2} \mathrm{O}_{5}$ içeriklerinin az (\%100), değişebilir $\mathrm{K}_{2} \mathrm{O}$ içeriğinin fazla, tekstürel açıdan \%50.0'sinin tınlı,\%42.0'sinin killi tın ve \%8.0’inin killi bünyeye sahip olduğu belirlenmiștir.
\end{abstract}

Anahtar Kelimeler: Tarım topraklarının verimlilik potansiyeli, Hınıs ovası tarım toprakları

\section{Assessment of Some Physical and Chemical Properties of Soils Different Plant Growth in Hinis-} Erzurum

\begin{abstract}
This study was undertaken for determining fertility potential of agricultural and grassland soils of Hinis plain, Erzurum. For this purpose total of 36 soil samples from $0-30 \mathrm{~cm}$ soil depth were collected from different land use areas (dry agricultural lands, irrigated lands and grasslands) in all over Hinis plain. Soil samples were analyzed for soil reaction $(\mathrm{pH})$, electrical conductivity (EC), $\mathrm{CaCO}_{3}$ content, organic matter content, plant available phosphorus $(\mathrm{P})$, cation exchange capacity (CEC), exchangeable $\mathrm{Na}$ and $\mathrm{K}$ and soil texture. The fertility status and productivity potential of district soils were evaluated by comparing the test results and the limit values of the measured soil properties. The results indicated that the soils in the study plain has neutral $(58.3 \%)$ or slightly alkaline $(41.7 \%)$ reaction without salt problem and having moderate $(75.0 \%)$ or high lime $(25.0 \%)$ contents. About $1 / 4$ of the plain soils have low content of organic matter, $58.3 \%$ moderate and $16.7 \%$ high amounts of organic matter. The plant available $\mathrm{P}_{2} \mathrm{O}_{5}$ was low $(100 \%)$ and $\mathrm{K}_{2} \mathrm{O}$ was high. Soil texture was either loamy $(50.0 \%)$ or clay loam $(42.0 \%)$, and a small portion was clay $(8.0 \%)$ textured.
\end{abstract}

Keywords: Fertility potential of farm soils, farm soils of Hinis plain

\section{GİRIS}

Doğal kaynakların en önemlisi ve yaşamımızın güvencesi olan toprak, üzerinde bitkisel üretim yapılan, barınma ve beslenme gibi ihtiyaçlarımızı karşılayan doğal varlıktır. Bu nedenle toprak, geçmişten-geleceğe tüm toplumlar için iktisadi, toplumsal ve siyasal açıdan çok büyük önem taşır.Çünkü toprak yenilenemeyen ve çoğaltılması mümkün olmayan bir kaynaktır. Nüfusununve dolayısıyla ihtiyaçların hızla artması, tarımsal üretimin arttırılmasını zorunlu kılmaktadır. Yeryüzünde bulunan mevcut tarım alanlarının artırılması çok güç hatta neredeyse imkânsızdır. Dolayısıyla birim alandan daha fazla ürün almaya yönelik çalışmalar yapılmalıdır. $\mathrm{Bu}$ çalışmalar çevreye ve canlılara zarar vermeyecek şekilde yapılmalıdır. Kimyasal gübrelerin kullanılmasının sebepleri, eksik besin elementlerini belirleyerek, ürün kalitesini artırmak, toprak verimliliğini belli seviyede tutmak, olumsuz şartlar için bitkilerin dayanıklılığını artırmaktır. (Güzel vd., 2002; Güçdemirvd., 2008).

Ülkemizin ürün çeşitliliğinin ve kendi kendine yetme özelliğinin devam edebilmesi için uygulanan tarımsal yöntemlerin geliştirilmesi, toprak özelliklerinin iyi analiz edilmesi, uygun teknik ve teknolojilerin kullanılması çok önemlidir. Toprakta eksik olan elementin cins ve miktarın tespit edip, tüm amaçlara hizmet eden bir uygulama ile toprağa geri kazandırılması gerekir. Bunun için toprak analizleri büyük önem taşımaktadır. Verimli bir toprak: bitkilere yeterli besin elementi, su ve oksijen gibi hayati faktörleri sağlayan topraktır. İstenilen miktarda ve kaliteli ürün elde edebilmek için eksik olan veya bitkiler tarafindan sömürülen besin elementlerinin toprağa geri kazandırılması gerekmektedir. Bilinçsiz ve yanlış yöntemler uygulanarak yapılan gübreleme hem ekonomik yönden maddi kayıp, hem de toprakların doğal yapısının bozulması, dolayısıyla üretkenliklerinin azalması yönünden sakıncalıdır. Toprak analizleri yanlış gübre kullanımını engellemek ve toprağa ihtiyacı olan miktarda gübreyi vermek amacı ile yapılmalı, analiz sonuçlarına göre uygun çeşit ve miktarda gübre kullanılmalıdır. Türkiye topraklarının besin elementi içeriğinin ve verimlilik potansiyelinin 
saptanması için değişik yörelerdenalınan 243.453 toprak örneğinde topraklarının fiziksel ve kimyasal özelliklerianaliz edilmiştir. (Eyüpoğlu, 1999).

Bitkisel üretimde en uygun gübre yönteminin seçilmesi ve dengeli bir şekilde uygulanması, çevreye ve doğaya zarar vermeyecek, ürün kalitesinive hedeflenen verimi düşürmeyecektir. Toprak analiz sonuçları dikkate alınmadan yapılan gübreleme, çok büyük ekonomik zararlara sebep olabilmektedir. Gübre önerileri usulüne uygun yöresel toprak çalışmalarına göre yapılmalıdır. Önce toprak analizleri ile toprağın besin elementi içeriğinin belirlenmesi daha sonra en uygun gübreleme miktarının ve metodunun seçilerek gübreleme yapılması gerekir. Toprak analizleri bilinçli ve dengeli gübreleme yapmak için göz ardı edilemeyecek kadar önemlidir. (Güzel vd.,2002;Kacar ve Katkat,2011).

Türkiye toprakların verimlilik durumu ve beslenme sorunlarını belirlemek amacıyla yapılançok sayıda araştırma ve analiz sonucundatopraklara ait bazı fiziksel ve kimyasal özellikler tespit edilmiştir.Araştırma sonuçlarına göre toprak özellikleri geniş bir değişim aralığında farklılıklar göstermektedir(Öztaş vd., 1997; Bozkurt vd., 2001; Tarakçıŏlu vd., 2003; Başaran ve Okant, 2005; Çimrin ve Boysan, 2006;Asri vd., 2008; Parlak vd., 2008; Turan vd., 2010; Bellitürk, 2011; Özyazıcıvd., 2013; Taşova ve Akın, 2013;Saraçoğlu vd, 2014).

$\mathrm{Bu}$ çalışmanın amacı Erzurum ili Hınıs ilçesinde farklı bitkilerin yetiştirildiği alanların bazı fiziksel ve kimyasal özellikler açısından karşılaştırılması ve Hınıs ovası topraklarının verimlilik durumunun belirlenmesidir.

\section{MATERYAL VE METOT}

Araştırmada,Erzurum ili Hınıs ovasından0-30 $\mathrm{cm}$ derinlikten alınan buğday ekili (kuru tarım) alanlarından 12, fasulye ekili (sulu tarım) alanlarından 12 ve çayır otu yetiştirilen alanlardan 12 olmak üzere (toplam 36 adet) toprak örneği kullanılmıştır. Hınıs ovasını temsil edecek şekilde alınan toprak örnekleri uygun koşullarda kurutulup, dövülüp, elenip, muhafaza edilerek gerekli rutin analiz yapılmıştır.

Toprakların pH'ları 1:2.5 toprak su süspansiyonunda (McLean, 1982), Elektriki iletkenlikleri(Rhoades, 1996), kireç içerikleri (Nelson, 1982), organik madde içerikleri (Nelson and
Sommers, 1982), tekstürleri (Gree and Hortage, 1986), KDK'leri (Rhoades, 1982a), değişebilir K ve $\mathrm{Na}$ (Rhoades, 1982b), elverişli fosfor içerikleri (Olsen and Sommers, 1982), istatistiksel değerlendirmeler ise SPSS 17.0 paket programı kullanılarak belirlenmiştir.

Erzurum ve Hınıs'ın Meterolojik Verileri, Arazi Varlığı, Kullanım Durumu ve Üretim Potansiyeli

Erzurum ili Doğu Anadolu Bölgesi'nde yer almakta olup, engebeli ve çevresi dağlarla kaplı $1.900 \mathrm{~m}$ rakımlı, yıllık ortalama sıcaklığ $5.7^{\circ} \mathrm{C}$, yıllık ortalama yağışı $411 \mathrm{~mm}$ ve ortalama nisbi nemi \%68.0'dır. Hınıs ilçesi ise Erzurum ilinin güneyinde yer almakta olup, engebeli ve çevresi dağlarla kaplı $1700 \mathrm{~m}$ rakımlı, yıllık ortalama sicaklık $8.5^{\circ} \mathrm{C}$, yıllık ortalama yağış $455 \mathrm{~mm}$ ve ortalama nisbi nem $\% 60.0$ 'dir (Anonim, 2016).

Erzurum ili 2,506,600 ha yüz ölçüme sahip ve bunun 347,800 ha' 1 tarım alanıdır. Tarımsal alanların 240,300 ha'ında tahıllar ve diğer tarla bitkileri, 4200 ha'ında bahçe bitkileri yetiştirilmekte ve 103,300 ha'ında nadas uygulanmaktadır. Hınıs ilçesi ise 128,300 ha alana sahip olup, bunun 20,000 ha tarım alanıdır. Tarım arazilerinin 15,500 ha'ında tahıllar ve diğer tarla bitkileri, 200 ha'ında bahçe bitkileri yetiştirilmekte ve 4300 ha'inda nadas uygulanmaktadır. Erzurum 74,150 ha, Hınıs 3,620 ha çayır alanına sahiptir(Anonim, 2015).

Üretim potansiyelleri açısından, Erzurum ili genel ortalaması ve Hınıs ilçesi ortalama verileri kıyaslandığında; Erzurum il genelinde buğday ekili alan 115,900 ha olup, toplam buğday üretimi 193,000 ton civarında ve ortalama verim $166 \mathrm{~kg} / \mathrm{da}$, Hınıs ilçesinde ise buğday ekili alan 8,950 ha, toplam buğday üretim 11,100 ton ve ortalama verim 124 $\mathrm{kg} / \mathrm{da}$ 'dır. Erzurum il genelinde buğday ekili 115,900 ha'lık alanın 38,200 ha'1 sulu, 77,700 ha'ı kuru tarım alanıdır. Sulu tarım alanlarında ortalama verim 232 $\mathrm{kg} / \mathrm{da}$, kuru tarım alanlarında $135 \mathrm{~kg} /$ da'dır. $\mathrm{Bu}$ veriler Hınıs için ise, toplam buğday ekili alan 8,950 ha, bunun 1,770 ha'1 sulu, 7,180 ha'1 kuru tarım alanıdır. Hınıs ilçe verilerine göre suluda buğday verimi ortalama $196 \mathrm{~kg} / \mathrm{da}$, kuru tarım alanlarında ise $106 \mathrm{~kg} / \mathrm{da}$ 'dır. (Anonim, 2015). Hem sulu hem de kuru koşullarda Erzurum il ortalama verimleri Hınıs ilçe ortalama verimlerinden \%20-30 daha yüksektir (Şekil 1). 


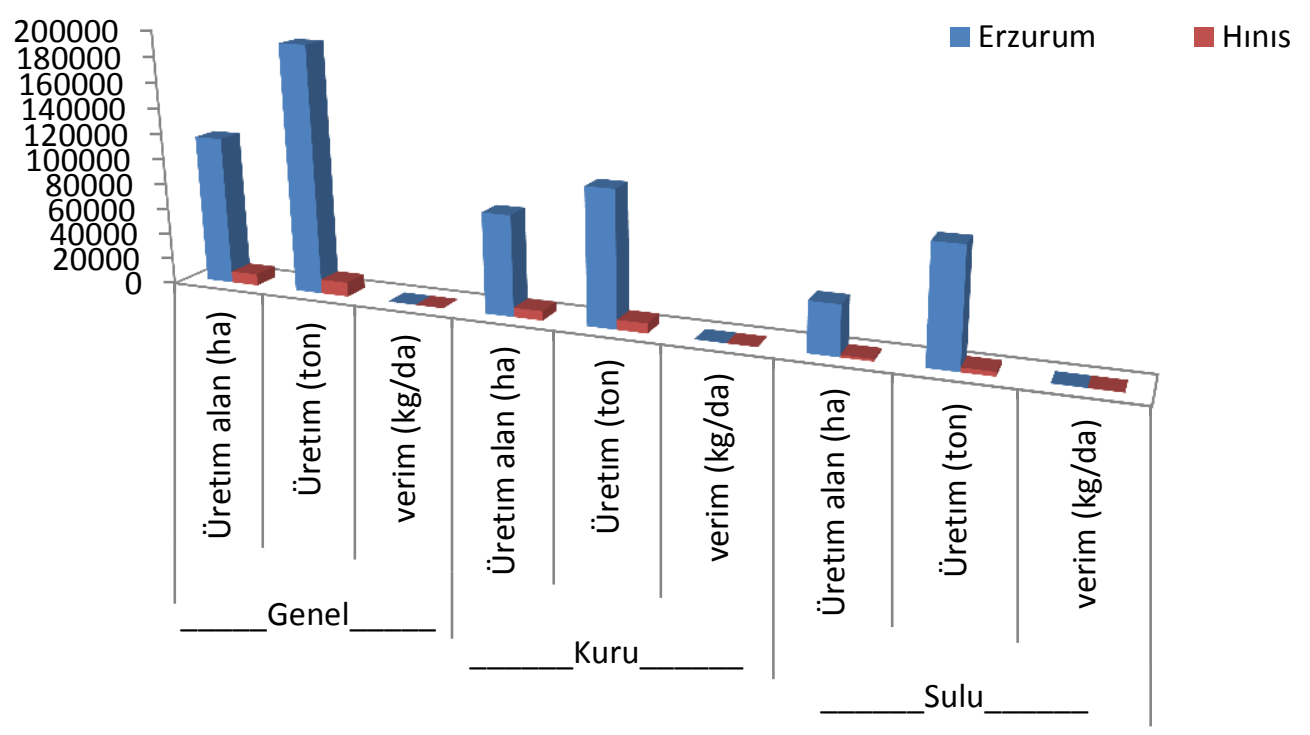

Şekil 1. Erzurum ve Hınıs’ın buğday ekim alanı, üretimi ve ortalama verimi (Anonim, 2015).

Verimdeki bu farklılık, yöre iklimsel özellikleri yanında Hınıs çiftçisinin henüz ürün arttırıcı girdiler ve teknolojik gelişmelerden (kimyasal gübre, kaliteli tohumluk, tarımsal mücadele vs.) yeterince haberdar olmadığının göstergesidir.

Erzurum genelinde fasulye ekili alan 1,210 ha,ortalama verim $213 \mathrm{~kg} / \mathrm{da}$ 'dır. Hınıs da ise fasulye ekili alan 245 ha, ortalama verim $193 \mathrm{~kg} / \mathrm{da}$ 'dır (Anonim, 2015). İl ve ilçe birim verimleri karşılaştırıldığında Erzurum ortalaması, Hınıs ortalamasından \%10 daha yüksektir (Şekil 2). Verimdeki bu farklılık, yöre özellikleri ve çiftçi kültüründen kaynaklanabilir.

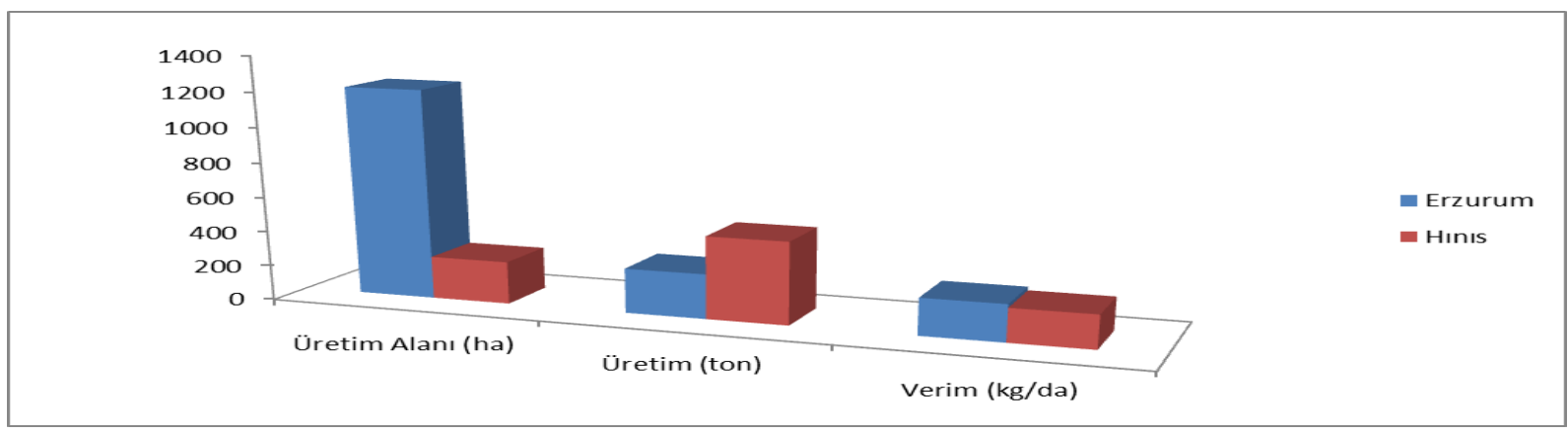

Şekil 2. Erzurum ve Hınıs'da fasulye yetiştirilen alan, üretim ve ortalama dekara verim

Erzurum il genelinde çayır alanı 74,150 ha ile toplam alanın yaklaşık \%3'üne tekabül etmektedir. Hınıs ilçesinde ise 3,620 ha çayır alanı mevcut olup, Hınıs ilçesi arazi varlığının yaklaşık \%2.8'ni oluşturmaktadır. Erzurum il genelinde ortalama çayır otu üretimi 330,000 ton civarında olup, ortalama verim $445 \mathrm{~kg} / \mathrm{da}$ 'dır. Hınıs ilçesinde ise çayır alanı 3,620 ha, ot üretimi 16,300 ton ve ortalama verim $450 \mathrm{~kg} / \mathrm{da}$ 'dır (Anonim, 2002). İl ve ilçe dekara verimleri karşılaştırıldığında verim değerleri benzerlik göstermektedir (Şekil 3). 


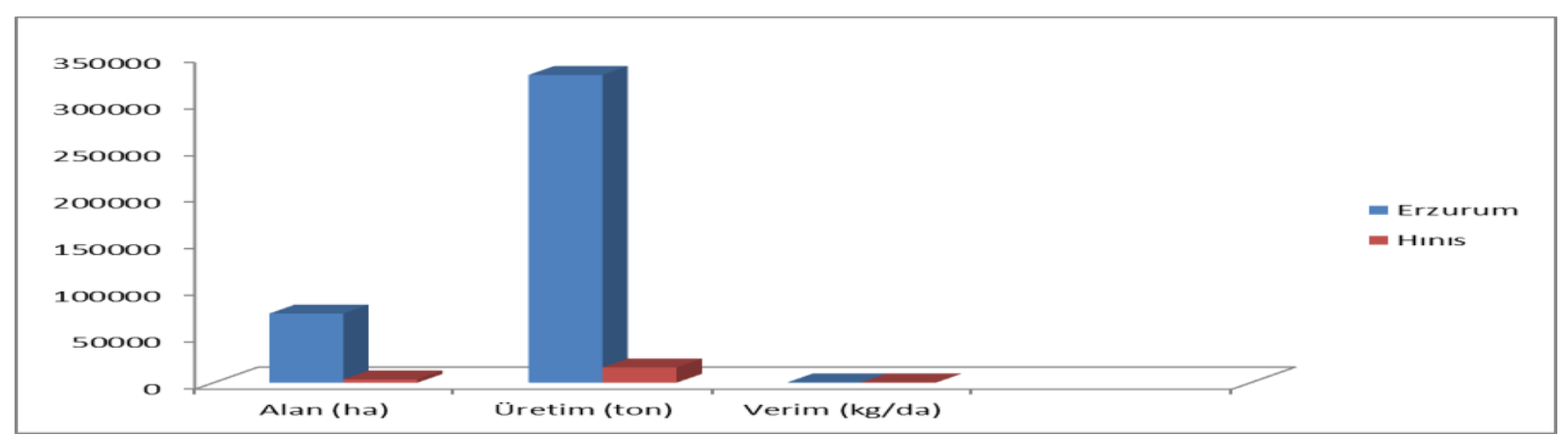

Şekil 3. Erzurum ve Hınıs'taki çayır alanı, ot üretim miktarı ve ortalama dekara ot verimi

ARAŞTIRMA BULGULARI

Erzurum ili Hınıs ilçesi toprak örneklerinin bazı fiziksel ve kimyasal özellikleri

Erzurum ili Hınıs Ovasından farklı kullanım şekli uygulananalanlardan alınan toprak örneklerinin bazı fiziksel ve kimyasal özelliklerine ait analiz sonuçları Çizelgede 1'de, toprak örneklerinin kimyasal özelliklerine ait korelasyon katsayıları da Çizelge 2'de yer almaktadır.

Analiz sonuçlarına göre $\mathrm{pH}$ ile kireç ve $\mathrm{Na}$ arasında, E.C. ile organik madde, kireç ve KDK, kireç ile Değişebilir Na, Değişebilir $\mathrm{K}$ ve $\mathrm{KDK}, \mathrm{Na}$ ile Değişebilir $\mathrm{K}$ ve KDK arasında önemli ilişkilertespit edilmiştir (Çizelge 2).

Çizelge1. Araştırma topraklarının bazı fiziksel ve kimyasal analiz sonuçlar

\begin{tabular}{|l|c|c|c|c|c|c|c|c|c|}
\hline $\begin{array}{c}\text { Kullanım } \\
\text { biçimi }\end{array}$ & $\begin{array}{c}\mathbf{p H :} \\
\mathbf{1 : 2 . 5}\end{array}$ & $\begin{array}{c}\mathbf{E C . 1 0} \\
\mathbf{d S} / \mathbf{m}\end{array}$ & $\begin{array}{c}\text { Kireç } \\
\mathbf{\%}\end{array}$ & $\begin{array}{c}\mathbf{O . M} \\
\mathbf{\%}\end{array}$ & $\begin{array}{c}\mathbf{P}_{\mathbf{2}} \mathbf{O}_{\mathbf{5}} \\
\mathbf{K g} / \mathbf{d a}\end{array}$ & $\begin{array}{c}\mathbf{K D K}, \\
\mathbf{m e / 1 0 0 g}\end{array}$ & $\begin{array}{c}\mathbf{D . K}, \\
\mathbf{m e} / \mathbf{1 0 0 g}\end{array}$ & $\begin{array}{c}\text { DNa, } \\
\mathbf{m e} / \mathbf{1 0 0 g}\end{array}$ & $\begin{array}{c}\text { Tekstür } \\
\text { sınıfi }\end{array}$ \\
\hline Buğday & $7.32 *$ & 0.414 & 11.7 & 2.46 & 3.56 & 21.3 & 1.21 & 0.39 & Killi-tın \\
\hline Fasulye & 7.25 & 0.547 & 11.5 & 1.69 & 3.40 & 22.6 & 1.60 & 0.35 & Killi-tın \\
\hline Çayır & 7.39 & 0.383 & 12.2 & 2.93 & 3.60 & 19.5 & 1.12 & 0.37 & Tın \\
\hline
\end{tabular}

*:Rakamsal değerler 12'şer toprak örneği ortalamasıdır.

Çizelge 2. Topraklarının kimyasal özellikleri arasındaki korelasyon katsayıları

\begin{tabular}{|l|l|l|l|l|l|l|l|}
\hline & pH & EC & Kireç & Org. Madde & Na & K & P \\
\hline EC & 0.201 & & & & & & \\
\hline Kireç & $0.580^{*}$ & 0.554 & & & & & \\
\hline Org. Madde & 0.243 & $-0.678^{*}$ & $-0,069$ & & & & \\
\hline Na & $0.676^{*}$ & 0,452 & $0,900^{* *}$ & $-0,029$ & & & \\
\hline K & 0.289 & $0,646^{*}$ & $0,604^{*}$ & $-0,544$ & $0,626^{*}$ & & \\
\hline P & 0.464 & 0,282 & 0,326 & $-0,043$ & 0,355 & 0,490 & \\
\hline KDK & 0.332 & $0,730^{* *}$ & $0,708^{*}$ & $-0,383$ & $0,644^{*}$ & 0,508 & 0,044 \\
\hline
\end{tabular}

\section{Araştırma bölgesi toprak örneklerinin pH} değerleri

Tarımsal faaliyetler ve kullanım durumları dikkate alınarak yapılan değerlendirme sonucuna göre buğday ekili alanlarda; en düşük pH değeri 6.91, en yüksek pH değeri 7.63 olmak üzere ortama değer 7.32'dir. Fasulye ekili alanlarda, en yüksek değer 7.53, en düşük değer 6.96 ve ortalama değer 7.25'dir. Çayır ekili alanlarda, en yüksek pH 7.56, en düşük $\mathrm{pH}$ değeri 7.26olmak üzere ortalama değer 7.39'dur. Araştırma alanından alınan 36 toprak örneğinin $\mathrm{pH}$ değerleri en düşük 6.91, en yüksek 7.63 olup ortalama $\mathrm{pH}$ değeri $7.32^{\prime}$ dir. $\mathrm{Bu}$ değerlere göre araştırma topraklarının nötr ve hafif alkalin reaksiyonda olduğu görülmektedir(Aydın ve Sezen, 1995). Erzurum'da yapılan farklı çalışmalarda toprak pH'sinın 6.86-8.82 (Yildiz ve Bilgin, 2008) ve 6.208.20 arasında değiştiği belirtilmektedir (Öztaş vd., 1997).

Toprakların pH'ları tarımsal faaliyetler için bir sorun teşkil etmemektedir. Çalışma topraklarının büyük çoğunluğunun $\mathrm{pH}$ değerleri nötr olduğu için besin elementleri açısından sorun teşkil etmez. $\mathrm{pH}$ değeri hafif alkalin olan diğer topraklarda önemli bir 
sorun olmamakla beraber dikkatli olunmalıdır. Gübreleme yapılırken toprak pH's1 mutlaka göz önünde bulundurulmalıdır. Bunun yanında pH'nın düşmesine veya yükselmesine sebep olacak tarımsal uygulanmalardan kaçınılmalıdır.

\section{Araştırma bölgesi toprak örneklerinin E.C. değerleri}

Çalışma alanına ait toprak örneklerinin tuz içerikleri (EC.10 ${ }^{3}$ ) en düşük değer $0.31 \mathrm{dS} / \mathrm{m}$, en yüksek değer $0.81 \mathrm{dS} / \mathrm{m}$ olup ortalama $0.45 \mathrm{dS} / \mathrm{m}$ ' dir. Yetiştirilen ürün dikkate alınarak değerlendirme yapıldığında, buğday ekili alanlarda; en düşük değer $0.33 \mathrm{dS} / \mathrm{m}$, en yüksek $0.48 \mathrm{dS} / \mathrm{m}$ ve ortalama $0.42 \mathrm{dS} / \mathrm{m}$ 'dir. Fasulye ekili alanlarda, en düşük değer $0.36 \mathrm{dS} / \mathrm{m}$, en yüksek değer $0.81 \mathrm{dS} / \mathrm{m}$ olup, ortalama 0.55 'dir. Çayır ekili alanlarda ise en düşük değer 0.31 $\mathrm{dS} / \mathrm{m}$, en yüksek değer $0.51 \mathrm{dS} / \mathrm{m}$ ve ortalama değer $0.39 \mathrm{dS} / \mathrm{m}$ olarak belirlenmiştir. Araştırmaya konu toprak örnekleri tuzsuz olup, bitki yetiştiriciliği açisından herhangi bir tuzluluk sorunuoluşturmamaktadır. Toprakların tuz miktarlarının artmaması için bilinçsiz gübreleme ve aşırı sulama gibi uygulamalardan kaçınılmalı, gübre ve sulama uygulamaları yapılmadan önce bölgenin iklim durumu dikkate alınmalıdır (Güçdemir, 2006).Erzurum ovasında yapılan çalışmada, toprakların \%69.0'unun tuzsuz, \%16.0'sinın hafif, $\% 6.0$ 'sının orta, \%6.0'sının şiddetli ve \%3.0'ünün çok şiddetli tuzlu olduğu belirlenmiştir (Özbek, 2003).

\section{Araştırma bölgesi toprak örneklerinin kireç} değerleri

Araştırma sahası toprak örneklerinin kireç içerikleri \%5.5 ile \% 26.3 arasında değişmekte olup, ortalama \%11.8'dir. Buğday ekili alanlarda en düşük kireç değeri \%5.8, en yüksek kireç değeri \%26.3 ortalama olarak da \%11.7 olarak bulunmuştur. Fasulye ekili alanlarda en düşük kireç miktarı \%5.5, en yüksek kireç değeri \%25.1 ve ortalama değer \%11.5'tur. Çayır ekili alanlarda en düşük değer $\% 5.8$, en yüksek değer \%24.1, ortalama değer ise \%12.2 olarak bulunmuştur. Araştırma alanının doğu kesiminden alınan 9 toprak örneğinin kireç içerikleri $\% 24.1$ ile \%26.3 arasında değişmekte olup, kireç içeriği oldukça yüksektir. Fazla ve çok fazla kireç içeren araştırma topraklarında sorunlarla karşılaşmamak için önlem alınmalıdır. Kireç miktarındaki yükselmeye bağlı olarak başta $\mathrm{P}$ olmak üzere $\mathrm{Fe}, \mathrm{Mn}, \mathrm{Zn}$ ve $\mathrm{Cu}$ gibi mikro besin maddeleri elverişliliğinde azalama söz konusudur. Gübreleme yaparken bu sorunlar dikkate alınarak mikroelement gübrelemesi de yapılmalıdır. Erzurum ovasından alınan 22 adet toprak örneğinin kireç içerikleri \%1.01 ile \% 13.97 (Yıldız ve Bilgin, 2008). Atatürk Üniversitesi çiftliğinden alınan 110 örneğin kireç içeriğinin $\% 0.2$ ile $\% 26.0$ arasında değiştiği saptanmıştır (Öztaş vd., 1997).

\section{Araştırma bölgesi toprak örneklerinin organik madde içerikleri}

Araştırma yapılan toprak örneklerinin organik madde içerikleri \%1.36 ile \%3.33 arasında olup ortalama \%2.36 olarak bulunmuştur. Buğday ekili alanlarda en düşük değer $\% 2.26$, en yüksek değer $\% 2.67$ ortalama değer \%2.46'dır. Fasulye ekili alanlarda en düşük değer \%1.36, en yüksek değer $\% 2.01$, ortalama\%1.69'dur. Çayır ekili alanlarda en düşük değer \%2.65, en yüksek değer \%3.33, ortalama değer ise \%2.92'dir. Çayır arazileri ile Buğday ekili alanlar genel olarak yeterli seviyede organik madde içermektedir (Aydın ve Sezen, 1995). Ancak çayır ve buğday ekili alanlara göre fasulye ekili alanların organik madde içerikleri genel olarak az düzeydedir. Buna neden fasulye tarımında toprak işlemenin daha yoğun yapılması, toprak işlemeye bağlı olarak toprak havalanması ve isınması dolayısıyla toprakta organik madde mineralizasyonunun hizlandirılması gösterilebilir. Fasulye ekili alanların organik madde içeriklerinin artırılması için bitki artıklı tarım, hayvansal gübre kullanımı, bitki rotasyonunda toprakta organik madde miktarını artıracak bitkilere yer verilmesi, bitki artıklarının tarla yüzeyinde bırakılması gibi çalışmalar yapılmalıdır. Erzurum yöresinde yapılan çalışmalarda (Yıldız ve Bilgin, 2008), analiz ettikleri toprak örneklerinde organik madde miktarını \%0.46-\%4.49, (Öztaş vd.,1997) ise $\% 1.30$ ile \%5.20. arasında bulmuşlardır.

\section{Araştırma bölgesi topraklarının fosfor değerleri}

Araştırma toprakları incelendiğinde en düşük fosfor değeri $3.21 \mathrm{~kg} / \mathrm{da}$, en yüksek fosfor değeri 3.97 $\mathrm{kg} / \mathrm{da}$ ve ortalama değer $3.59 \mathrm{~kg} / \mathrm{da}$ olarak belirlenmiştir. Fosfor değeri incelenen tüm topraklarda yetersiz seviyededir (Aydın ve Sezen, 1995). Bu durum bize, yeterince fosforlu gübreleme yapılmadığını göstermektedir. Uygun bir gübreleme programı ile toprakların fosfor miktarları artırılabilir.

\section{Araştırma bölgesi topraklarının KDK ile Değişebilir K ve Na değerleri}

İncelenen toprakların KDK'leri15.8 ile 25.2 me/100g arasında değişmekte olup, genel olarak düşüktür. Erzurum ovasında yapılan çalışmada toprak örneklerinin KDK değerleri 20.4-55.6 me/100 $\mathrm{g}$ arasında bulunmuştur (Yıldız ve Bilgin, 2008). Toprakların katyon değişim kapasiteleri, besin elementlerinin toprakta tutulması ve bitki beslenmesi açısından büyük önem taşımaktadır. Toprakta katyon değişim kapasitesinin yüksek olması toprak organik maddesi ile kil tipi ve miktarına bağlıdır. Çalışma yöresi toprak örneklerinin $\mathrm{K}$ değerlerinin 0.61 
me/100 g ile $1,91 \mathrm{me} / 100$ gr arasında değiştiği görülmektedir. 36 toprak örneğinin ortalama $\mathrm{K}$ değeri 1.31 'dir. $\mathrm{Bu}$ değerlere göre sinıflandırma yapıldığında toprak örnekleri $\mathrm{K}$ açısından çok ve çok fazla sinıfina girmektedir. Potasyumun bakımından herhangi bir sorun söz konusu değildir. İncelenen toprak örneklerinin $\mathrm{Na}$ değerleri $0.31 \mathrm{me} / 100 \mathrm{~g}$ ile $0.63 \mathrm{me} / 100$ arasında değişmekte olup, ortalama değişebilir $\mathrm{Na}$ içeriği $0.36 \mathrm{me} / 100$ g'dır. Na açısından bir sorun teşkil etmemektedir(Aydın ve Sezen, 1995).

\section{Araştırma bölgesi toprak örneklerinin tekstür sınıfları}

Araştırma kullanılan toprak örneklerinin tekstür sınıfları incelendiğinde, genel olarak tın ve killi tın olduğu görülmektedir (Demiralay, 2013). Araştırma toprakları genel olarak orta ve ince bünyelidir. Erzurum ovasına ait 22 toprak örneği üzerinde tekstür sınıfını belirlemek amacı ile yapılan çalışmaya göre, toprakların kil içeriği \%4.9-30.3, silt içeriği \%27.5-51.9 ve kum içeriği \%36.5-64.4 arasında değişmektedir (Yıldız ve Bilgin, 2008).

\section{SONUÇ ve ÖNERILER}

Araştırma yöresi toprak örneklerinin pH'ları 6.91-7.63 arasında olup nötr ve hafif alkalindir. Toprakların pH'sı bitki besleme ve bitkisel üretim açısından sorun oluşturmamaktadır.

İncelenen toprak örneklerinin kireç içeriği \%5.53-\%26.30 arasında olup, ortalama \%11.8'dir. Hınıs ilçesinin doğu kesiminden alınan toprak örneklerinin kireç içeriği (\%25.0 civarında) yüksektir. Gübre uygulamalarında toprakların kireç içeriği dikkate alınmalıdır.

Tuzluluk bakımından araştırma alanı toprak örneklerinin E.C.10 ${ }^{3}$ değerleri $0.31-0.81 \mathrm{dS} / \mathrm{m}$ olup, ortalama $0.45 \mathrm{dS} / \mathrm{m}$ 'dir. Analiz edilen 36 toprak örneğinde tuzluluk sorunu yoktur.

Araştırma bölgesi toprak örneklerinin organik madde içeriği \%1.36 ile \%3.33 arasında değişmekte olup, ortalama \%2.36ile orta düzeydedir. Yörede toprak organik madde miktarını arttırıc1 uygulamalara (bitki artıklı tarım, hayvan gübresi, bitki rotasyonu vs) yer verilmelidir.

Analiz edilen toprakörneklerinin fosfor içeriği $3.21 \mathrm{~kg} / \mathrm{da}$ ile $3.97 \mathrm{~kg} / \mathrm{da}$ arasında olup yetersizdir. Uygun bir gübreleme programı ile toprakların fosfor miktarları artırılabilir.

Toprak örneklerinin kum içerikleri \%30-46, silt içerikleri \%26-40 ve kil içerikleri \%12-40 arasında değişmektedir. Tekstürel açıdan analiz edilen topraklarorta ve ince bünyelidir.

Çalışma topraklarıelverişli $\mathrm{K}_{2}$ Oiçeriği (0.61$1.91 \mathrm{me} / 100 \mathrm{gr}$ )yönünden yeterli düzeydedir (Aydın ve Sezen,1995).
Araştırma topraklarının en düşük KDK değeri 14.8, en yüksekKDK değeri 25.2 olup, KDK değerleri genel olarak düşüktür. Yöre topraklarının organik madde içerikleri arttırılmak suretiyle KDK'leri arttırılabilir.

Toprak verimliliğinin sürdürülebilirliği açısından yalnızca besin elementi sağlamak yeterli olmayıp, diğer tarımsal uygulamalar ve önlemlerde bu açıdan çok büyük bir öneme sahiptir. Toprakların uzun süre verimliliklerini ve kalitelerini sürdürebilmeleri için belirli aralıklarla analizlerinin yapılması gerekmektedir. İklim ve bitki faktörü kadar önemli olan toprak amenajmanı yanlış uygulandığında toprak verimliliğini sınırlandırıcı ve hatta toprak bozulmasına yol açan bir etmen haline gelebilir. Gübreleme ve amenajman programı hazırlanırken mutlaka toprak analizleri yapılmalı ve en uygun yöntemler tercih edilmelidir. Topraklar $\mathrm{pH}$ yönünden sorun teşkil etmemekle beraber dengenin bozulmaması için gübre kullanımında dikkatli olunmalıdır. Topraklarda tuzluluk bakımından da bir problem yoktur fakat bilinçsiz ve aşırı sulama uzun vadede sorun teşkil edebilir. Toprakların organik madde içerikleri genel olarak yeterlidir. Fasulye bitkisinin yetiştirildiği alanlarda organik maddenin düşük olması fazla toprak işlemeye bağlanabilir. $\mathrm{Bu}$ alanda çiftlik gübresi kullanmak ve yeşil gübreleme yapmak fayda sağlayabilir. Aynı şekilde çayır alanlarında organik maddenin yüksek olma sebebi bu alanların toprak işlemeli tarıma açık olmaması dolayısıyla fazla işlenmemesidir. Özellikle yöre çiftçilerinin gübre ve gübreleme, sulama, sertifikalı tohumluk kullanımı, tarımsal mücadele ve modern tarım araç-gereçlerinin kullanımı konularında bilinçlendirilmesi gerekmektedir. Ayrıca yöre toprak özelliklerinin ortaya konulması, başta çiftçiler olmak üzere tarımla uğraşanların bilgilendirilmesi ve bilinçlendirilmesi yönündekiçalışmalara önem verilmelidir.

\section{KAYNAKLAR}

Anonim, 2002. İl Tarım ve Kırsal Kalkınma Master Planlarının Hazırlanmasına Destek Projesi. Erzurum Tarım Master Planı, Tarım ve Köyişleri Bakanlığı.

Anonim, 2015. Türkiye İstatistik Kurumu Verileri.

Anonim, 2016. Devlet Meteoroloji İşleri Genel Müdürlüğü Verileri.

Asri, F. Ö., Arı, N., Arpacıoğlu, A. E., Demirtaş, E. I., Aslan, D. H., 2008. Antalya yöresinde domates yetiştirilen sera topraklarının bazı verimlilik özelliklerinin belirlenmesi. 4 . Ulusal Bitki Besleme ve Gübreleme Kongresi Konya 2008, 998-1005.

Aydın, A., ve Sezen, Y., 1995. Toprak Kimyası Laboratuvar Kitabı. Atatürk Üniversitesi Ziraat Fakültesi Ders Yayınları No: 174.

Başaran, M.,Okant, M., 2005. Bazı toprak özelliklerinin eldivan yöresinde yetiştirilen kirazların beslenme durumu üzerine etkisi. Tarım Bilim. Derg. 2005, 11(2):115-119. 
Bellitürk, K., 2011. Edirne İli Uzunköprü İlçesi tarım topraklarının beslenme durumlarının belirlenmesi. Tekirdağ Ziraat Fakültesi Dergisi 2011, 8(3):8-15.

Bozkurt, M. A.,Yarılgaç, T., Çimrin, K. M., 2001. Çeşitli meyve ağaçlarında beslenme durumlarının belirlenmesi. Yüzüncü Y1l Üniv., Ziraat Fak., Tarım Bilimleri Dergisi 2001, 11(1): 39-45.

Çimrin, K. M., Boysan, S., 2006. Van yöresi tarım topraklarının besin elementi durumları ve bunların bazı toprak özellikleri ile ilișkisi. Yüzüncü Yıl Üniversitesi Ziraat Fakültesi Tarım Bilimleri Dergisi 2006, 16(2): 105-111.

Demiralay, İ.,2013. Toprak Fiziksel Analizleri. Atatürk Üniv. Ziraat Fak. Ders Yayın. No:143

Eyüpoğlu, F., 1999. Türkiye Topraklarının Verimlilik Durumu. Toprak ve Gübre Araştırma Enstitüsü Yayınları Genel Yayın No: 220 Teknik Yayın No: T-67, Ankara.

Gree, G. W., ve Hortage, K. H., 1986. Particle-Size Analysis. Methods of soil Analysis. Part 1. Physical and Minerological Methods Second Edition. Agronomy No. 9. P:383-441

Güçdemir, İ. H., 2006. Türkiye Gübreler ve Gübreleme Rehberi. T.C T.B.K. TAGEM Toprak ve Gübre Araștırma Enstitüsü Müdürlüğü Yayınları Genel Yayın No:231, Teknik Yayınlar No: T.69, Ankara

Güçdemir, İ. H., Türker, U., Karabulut, A., Usul, M., Bozkurt, M., Arcak, Ç., 2008. Çukurova'da mısır tarımında hassas tarım tekniklerini kullanarak değissken oranlı gübre uygulamaları. 4. Ulusal Bitki Besleme ve Gübreleme Kongresi Konya 2008, 116-125.

Güzel, N., Gülüt, Y. K., ve Büyük, G., 2002. Toprak Verimliliği ve Gübreler Ders Kitabı. Ç. Ü. Ziraat Fak. Genel Yayın No: 246, Ders Kitapları Yayın No: A-80 Adana.

Kacar, B., ve Katkat, V. A., 2011. Gübreler ve Gübreleme Tekniği. Nobel yayın, 4. Basım. Nobel yayın No: 21,1. Basım, ISBN 978-605-5426-20-0, Mart 2011, 559, Ankara.

IBM, SPSS Statistics19.0, 2010

McLean, E. O., 1982. SoilpHand Lime Requirement. Methods of Soil Analysis Part 2. Chemical and Microbiological Properties Second Edition. Agronamy. No: 9 Part 2. Edition P: $199-224$.

Nelson, D. W., ve Sommers, L. E., 1982. OrganicMatter. Methods of Soil Analysis Part 2. Chemical and Microbiological Properties Second Edition. Agronamy. No: 9 Part 2. Edition P: 574-579.

Nelson, R. E., 1982. Carbonate and Gypsum. Methods of Soil Analysis Part 2. Chemical and Microbiological Properties Second Edition. Agronamy. No: 9 Part 2. Edition P:191197.

Olsen, S. R., ve Sommers, L. E., 1982. Phosphorus. Methods of Soil Analysis Part 2. Chemical and Microbiological
Properties Second Edition. Agronamy. No: 9 Part 2.Edition P: 403-427.

Özbek, A. K., 2003. Karasu Ovası topraklarının tarım potansiyelinin belirlenmesi. Atatürk Üniversitesi Ziraat Fakültesi Dergisi 2003, 34(4): 309-316.

Öztaş, T., Aydın, A., Canbolat, M. Y., Akgül, M., Turan, M., 1997. Atatürk Üniversitesi Ciftliği topraklarının kimyasal özelliklerinin irdelenmesi II. Kimyasal özellikler. Atatürk Üniversitesi Ziraat Fakültesi Dergisi 1997, 28(1): 49-63.

Özyazıcı, M. A., Dengiz, O., Sağlam, M., 2013. Artvin İlinde yonca tarımı yapilan toprakların verimlilik durumu ve potansiyel beslenme problemlerinin ortaya konulması. Artvin Çoruh Üniversitesi Orman Fakültesi Dergisi 2013, 14(2): 225-238

Parlak, M., Fidan, A., Kızılcık, İ., ve Koparan, H., 2008. Eceabat İlçesi (Çanakkale) tarım topraklarını verimlilik durumlarının belirlenmesi. Ankara Üniversitesi Ziraat Fakültesi Tarım Bilimleri Dergisi 14(4): 394-400.

Rhoades, J. D., 1982a. Cation Exchange Capacity. Methods of Soil Analysis Part 2. Chemical and MicrobiologicalProperties Second Edition. Agronamy. No: 9 Part 2. Edition P: 149157.

Rhoades, J. D., 1982b. Exchangeable Cations. Methods of Soil Analysis Part 2. Chemical and Microbiological Properties Second Edition. Agronamy. No:9 Part 2. Edition P:159-164.

Rhoades, J. D., 1996. Salinity: Electrical Conductivity and Dissolved Soilds. In: Methods of Soil Analysis Part III. Chemical Methods 2 Edition. Agronamy. No: 15, Madison, Visconsin. USA, P: 417-436.

Saraçoğlu, M., Sürücü, A., Koşar, İ., Anlağan Taş, M., Aydoğdu, M., Kara, H., 2014. Şanlıurfa İli Halfeti İlçesi topraklarının bazı özellikleri ve bitki besin elementi kapsamlarının belirlenmesi. Toprak Bilimi Ve Bitki Besleme Dergi. 2014, 2(2): 38-45.

Taşova, H., Akın, A., 2013. Marmara Bölgesi topraklarının bitki besin maddesi kapsamlarının belirlenmesi, veri tabanının oluşturulması ve haritalanması. ToprakSu Dergisi 2 (2) : 8395.

Tarakçığlu, C., Yalçın, S. R., Bayrak, A., Karabacak, H., 2003. Ordu yöresinde yetiștirilen findık bitkisinin (Corylus Avellana L.) beslenme durumunun toprak ve bitki analizleri ile belirlenmesi. Ankara Üniversitesi Ziraat Fakültesi Tarım Bilimleri Dergisi, 9(1): 13-22.

Turan, M. A.,Katkat A. V., Özsoy, G. Ve Taban S., 2010. Bursa İli alüviyal tarım topraklarının verimlilik durumları ve potansiyel beslenme sorunlarının belirlenmesi. U. Ü. Ziraat Fakültesi. 24(1): 115-130.

Yıldız, N., Bilgin, N., 2008. Erzurum Ovası topraklarının fosfor ve potasyum durumunun neubauer fide yöntemi ile belirlenmesi. Atatürk Üniversitesi Ziraat Fakültesi Dergisi, 39(2): 159-165. 